\title{
Productive and Reproductive Performance and Metabolic Profile of Barki Ewes Supplemented with Two Forms of Probiotics as Feed Additives
} \author{
Mohamed Tarek Badawy ${ }^{1}$ and Hany Mahmoud Gado ${ }^{3}$ \\ ${ }^{1}$ Animal and Poultry Physiology Department, Desert Research Center, 11753, Cairo, Egypt \\ ${ }^{2}$ Animal and Poultry Nutrition Department, Desert Research Center, 11753, Cairo, Egypt \\ ${ }^{3}$ Animal Production Department, Faculty of Agriculture, Ain Shams University, Cairo, Egypt \\ *Corresponding author`s Email: moharramf@yahoo.com; ORCID: 0000-0002-6067-0503
}

Ahmed Sobhy El-Hawy ${ }^{1}$, Moharram Fouad El-Bassiony ${ }^{*}$, Salah Abo Bakr ${ }^{2}$, Hamdi Abdel-Aziz Gawish ${ }^{1}$,

\begin{abstract}
Present study aimed to evaluate the impacts of probiotic mixtures as a biological feed additive on the reproductive and productive performance of Barki ewes under desert conditions. A total number of 100 Barki ewes were randomly assigned and divided into five equal groups (20 each) to evaluate the effect of different levels and forms of biological additives mixtures on Barki ewes productivity. The first mixture of probiotic added as liquid forms (Mixture Probiotic Liquid, MPL), while the second added as powder forms (Mixture Probiotic Powder, MPP). The two forms of enzymes used at two levels $(6$ and $10 \mathrm{ml}$ or $\mathrm{g} / \mathrm{h} / \mathrm{d})$. The two additives formed of exogenous enzymes and obtained through an anaerobic fermentation process of Ruminococcus flavefaciens. The results indicated that feed intake was higher in MPL and MPP treated groups compared to control group. During pregnancy and lactation stages, MPL and MPP groups recorded significantly increase in ewes body weight. The conception and lambing rates were tended to differ between groups, but the number of lambs born alive was significantly higher in MPP groups [19 lambs for group 2 (G2) and 18 lambs for group 3 (G3)] followed by MPL groups (16 and 18 lambs for group 4 (G4) and group 5 (G5), respectively), while the control group recorded 18 lambs. The mortality rate from birth to weaning decreased $(\mathrm{P}<0.05)$ in treated groups with 5\%,5\%,0\% and 5\% for G2, G3, G4 and G5, respectively, while the mortality rate increased $(\mathrm{P}<0.05)$ by $11 \%$ in control group. The milk yield tended to increase in MPP then MPL groups. The birth and weaning weights as well as average daily gain increased $(\mathrm{P}<0.05)$ in MPL and MPP groups. Thyroid hormones $\mathrm{T}_{3}$ and $\mathrm{T}_{4}$ concentrations increased $(\mathrm{P}<0.05)$ with enzymes mixtures supplementations. In conclusion, under the semi-arid conditions, supplementation of exogenous enzyme preparations of MPL and MPP to sheep rations, may improve weaning weight and daily gain of lambs as much as live body weight and milk production of ewes.
\end{abstract}

Key words: Biological additives, Productive performance, Reproduction, Milk, Barki sheep

\section{INTRODUCTION}

The economical and efficient production of sheep for meat, milk and others products depended on proper feeding, husbandry practices, and health care. All of these are influenced by dietary intake. The nutritional requirements for maintenance, reproduction, growth, finishing, and other production are complex because sheep are maintained under a wide variety of environmental conditions. However, attempts should be made to ensure that each production unit or individual sheep has adequate nutrient intake to be healthy and productive.

Worldwide demand for animal based products is increasing at a booming rate thus, emphasizing the necessity of applying strategies to improve animal productivity (Sujani and Seresinhe, 2015). The major constraints in today's livestock sector are high feed cost and low quality of available feed resources, especially in tropical developing countries (Fahmy et al., 2010 and Helal et al., 2018a). In arid and semi-arid regions small ruminants have a great importance (Helal et al., 2018b). They are often raised on grazing forage with little or no supplementation (El Shaer, 2004 and Aziz, 2009). Nutritional status is a major factor influencing an animal's ability to maintain health and reproduction (GrazulBilska et al., 2007). Over the years, animal nutritionists have developed various physical, chemical and biological methods to overcome the problems associated with livestock feed stuffs. As a biological treatment, method of utilizing exogenous enzymes has attracted attention of researches and it has become a widely discussed theme among animal nutritionists (McAllister et al., 2003). Abo Bakr (2012) suggested that enzymes can improve nutritive value of low quality roughage and bridging the feed gap for small ruminant nutrition.

The mixture of probiotic, Mixture Probiotic Liquid (MPL) and Mixture Probiotic Powder (MPP), which prepared from anaerobic bacterium, has been improved rumen fermentation, nitrogen balance, nutrient digestibility and milk yield of cows fed rations containing Egyptian by-product feeds (Gado et al., 2007), as well as gaining live weight and feed conversion of wheat straw in sheep and goats (Gado and Salem, 2008). The probiotic mixture containing enzymes such 
as cellulases, xylanases, $\alpha$-amylase and proteases from an anaerobic bacterium, showed a positive effect on ruminant performance and nutrient utilization of low quality roughage in vivo (Gado, 1997) and in vitro (Gado et al., 2007).

Proposed modes of action of direct-fed enzymes include solubilization of dietary fiber before ingestion, provision of readily fermentable substrate for ruminal microorganisms and/or enhancement of microbial enzyme activity in the rumen (McAllister et al., 2001). Gado et al. (2009) observed that the addition of enzymes increased intake of Dry Matter (DM). Organic Matter (OM) was positively influenced by supplementation. Digestibility of all nutrients was higher in the total tract of supplemented cows with $40 \mathrm{~g}$ of MPP/h/ day, although the magnitude of the improvement varied among nutrients, with the highest improvement was in Neutral Detergent Fiber (NDF) and Acid Detergent Fiber (ADF) than other nutrients.

Sheep in North Western coast of Egypt may play a significant role in improving the animal production sector in the country (Abdalla et al., 2015). Because the farmers are able to provide its requirements and the simplicity of selling sheep especially in Religious festivals. One of the major Egyptian sheep breed is Barki (Ibrahim et al., 2018), which is highly adapted to local conditions (Nassar et al., 2017). It is the smallest breed, with white wool and a brown neck. Purebred Barki is the choice of Bedouins in the desert. All are fat-tailed sheep. What distinguishes fat-tailed sheep from other sheep is their long tails, filled with fat and having a function similar to the camel's hump. These sheep are raised mainly for lamb production, followed by wool and milk (Helal et al., 2018b).

The objective of this study was to evaluate the impacts of two forms and levels of probiotic mixture (multi-enzyme preparations, bacteria, ...etc.) as a biological feed additives supplemented to sheep rations and its effect on the reproductive and productive performance as well as milk production and composition of Barki ewes under the environmental conditions of North Western coast of Egypt.

\section{MATERIALS AND METHODS}

\section{Experimental region}

The present study was carried out at the Animal Production Unit in the Sustainable Development Center for Matrouh Resources, Matrouh governorate, belongs to Desert Research Center in the North Western Coast of Egypt.

\section{Ethical approval}

This experiment was performed according to all ethics and animal rights (Desert Research Center). As much as this work had considering all rules and regulations in conformity with the European union directive for the protection of experimental animals (2010/63/EU).

\section{Experimental animals, rations and probiotic mixture}

One hundred Barki ewes, 2-3 years old and $38.9 \pm 1.02 \mathrm{~kg}$ average body weight were used. Animals were kept in individual pens roofed with wood, and were clinically healthy and free from internal and external parasites. The MPL is a liquid multi-enzyme preparation produced from Ruminococcus flavefaciens at the concentration of $28 \times 10^{4} \mathrm{CFU}$ with one gram of corn flour per each gram of the additive, while the MPL contains $11 \times 10^{3} \mathrm{CFU}$ of the same bacteria with one $\mathrm{ml}$ of water per each $\mathrm{ml}$ of the additive. The exogenous enzyme of MPL is a biotechnical solution product made from natural sources to elevate the level of cellulose enzyme from anaerobic bacteria and contained some specific enzymes such as cellulose $(8.2 \mu / \mathrm{g})$, hemicellulose $(6.2 \mu / \mathrm{mg})$, amylase $(64.4 \mu / \mathrm{g})$ and protease $(12.3 \mu / \mathrm{g})$. While, MPP is a biotechnical powder product contained similar enzymes of MPL plus bacteria and Saccharomyces cerevisiae yeast.

Biological additives of multi-probiotic (i.e., MPL or MPP) were mixed well with concentrated rations before feeding. Rations were adjusted biweekly according to weight of animals to cover their requirements during their different physiological status according to Kearl (1982). Animals were fed three weeks as a transitional period, on the tested rations before the start of the experiment. Fresh water was available to all groups daily. Samples from roughage and concentrate mixture were taken monthly to determine their chemical composition according to AOAC (1990) (Table 1). Mating season started in May month and lasted for 34 days (equal to two estrous cycles). Five fertile rams were allowed to rotate among different ewe groups to avoid ram/group confounding effect. Rams were fed the control concentrate ration and removed from the ewe groups at early morning before offering rations. Once lambing took place, the born lambs were ear tagged and weighed to record their birth weight and then biweekly till weaning that took place at three months old then weaning weight was recorded and adjusted for 90 days.

Table 1. Chemical composition of concentrate feed mixture and bean straw

\begin{tabular}{lccccccccc}
\hline \multirow{2}{*}{ Items } & \multirow{2}{*}{ DM } & \multicolumn{7}{c}{ Chemical composition on DM basis $(\mathbf{g} / \mathbf{k g}$ DM) } \\
\cline { 3 - 9 } & & $\mathbf{O M}$ & $\mathbf{C P}$ & NDF & ADF & EE & NFE & TDN* & DCP** \\
\hline Concentrate feed mixture & 914.3 & 876.7 & 123.5 & 430.1 & 250.3 & 23.4 & 599.1 & 692.11 & 79.53 \\
Bean straw & 907.1 & 842.7 & 64.7 & 598.8 & 428.9 & 15.1 & 428.0 & 522.47 & 24.91 \\
\hline
\end{tabular}

CFM: concentrate feed mixture; BS: bean straw; DM: dry matter; OM: organic matter; CP: crude protein; NDF: Neutral detergent fiber; ADF: Acid neutral detergent fiber; EE: ether extract; NFE: nitrogen free extract; *calculated total digestible nutrient according to Adams et al., (1964); ** calculated digestible crude protein according to Shaltout et al., (2012). 


\section{Experimental design}

Animals were randomly selected and divided into five equal groups (20 individuals each). The first group severed as control group and were fed on Concentrate Feed Mixture (CFM) without any additives, the second and third groups were fed CFM supplemented with 6 and $10 \mathrm{~g} / \mathrm{h} / \mathrm{d}$ from MPP, respectively. While the fourth and fifth groups were fed CFM supplemented with 6 and $10 \mathrm{ml} / \mathrm{h} / \mathrm{d}$ MPL, receptively. All groups were offered same roughage as Bean (Phaseolus vulgaris) straw and CFM according to physiological status.

\section{Blood sampling and hormonal assay}

Blood samples were collected from all the ewes through vein puncture (using clinical needle) twice (on day 130 and 140 of pregnancy) at eight am before the morning feeding. Blood samples were centrifuged at $3000 \mathrm{rpm}$ for 20 minutes for the separation of serum and kept at $-20^{\circ} \mathrm{C}$ until further analysis. Thyroid hormones (T3 and T4) were measured by ELISA method using immunospec kits (immunospec corporation, 7018 Owensmouth Ave, suite 103 Canoga park, CA 91303, USA).

\section{Milk samples and analysis}

Milk samples $(50 \mathrm{ml})$ were taken biweekly from individual ewes within the respective groups during 12 weeks lactation period, in plastic bottle and kept under $-20^{\circ} \mathrm{C}$ for further analysis. Milk yield were recorded biweekly from lambing up to 12 weeks lactation period, representing early (up to the fourth week), mid (up to the eighth week) and late lactation periods (up to the $12^{\text {th }}$ week), using lamb-suckling technique (Mousa and Shetawi, 1994) plus hand milking. Lambs were separated from their mothers at 8.00 p.m. on the day before measuring milk production. In the following day, lambs were weighed at 8.00 a.m., and left to suckle their dams till satisfaction, then reweighed and kept away from their mothers. While, the residual milk in the udder of each ewe was hand milked and weighed. Chemical composition of milk in terms of fat, protein, lactose, total solids and solids not fat was determined using milk scan (MilkoScan FT6000 and Bentley, Belguim).

\section{Statistical analysis}

A general linear method procedure (SAS, 2004) was used for the statistical analysis of this experiment using the following two models:

Model one for lamb weights, milk composition and thyroid hormones:

$\mathrm{Y}_{\mathrm{ij}}=\mu+\mathrm{T}_{\mathrm{i}}+\mathrm{e}_{\mathrm{ij}}$

Where,

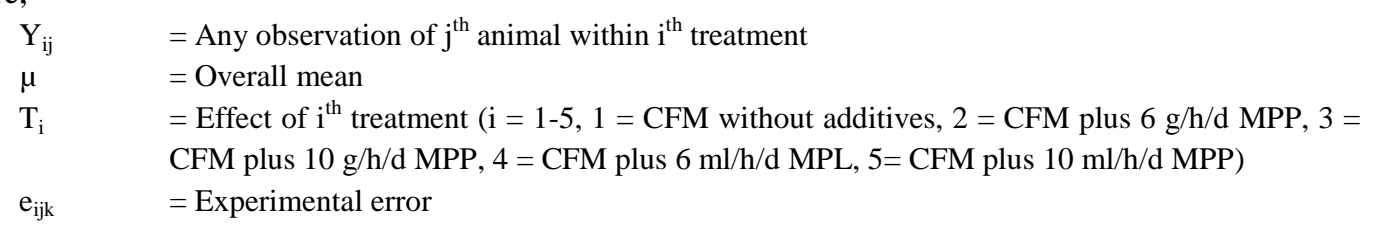

Model two for feed intake and milk yield:

$\mathrm{Y}_{\mathrm{ijk}}=\mu+\mathrm{T}_{\mathrm{i}}+\mathrm{S}_{\mathrm{j}}+(\mathrm{T} * \mathrm{~S})_{\mathrm{ij}}+\mathrm{e}_{\mathrm{ijk}}$

Where,

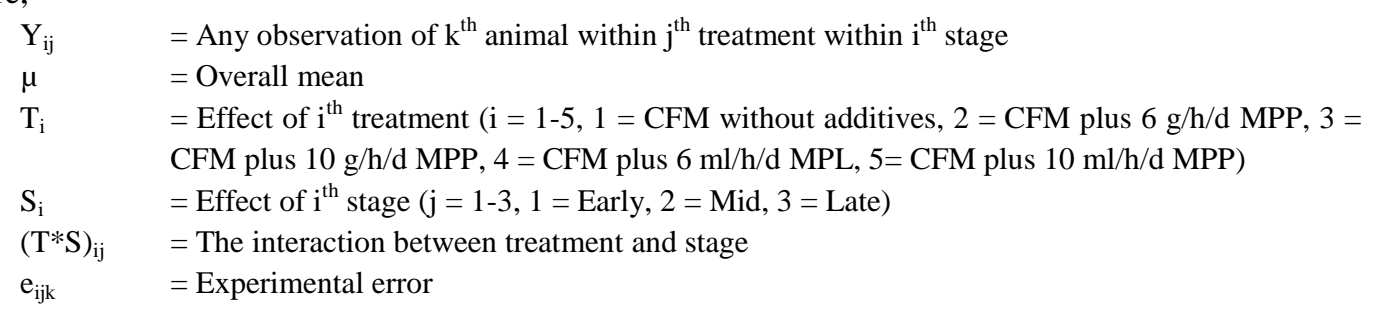

All statements of significance are based a probability of less than 0.05. Significant differences among means were detected using Duncan's multiple range test (Duncan, 1955).

\section{RESULTS AND DISCUSSION}

\section{Feed intake and live body weight changes of Barki ewes}

Feed intake of ewes during pregnancy and lactation periods did not differ $(\mathrm{P}<0.05)$ among MPL and MPP ewe groups. The MPL and MPP supplementation increased $(\mathrm{P}<0.05)$ body weights in all stages. Ewes of MPL groups recorded the best values of body weight during all stages followed by MPP groups compared to control group. The highest value from all stages in body weight changes was observed in G3 (with $10 \mathrm{~g} / \mathrm{h} / \mathrm{d}$ of MPP) with values $7.9 \mathrm{~kg}$ (Tables 2 and 3 ). 
Feed intake is a factor which should be closely linked to the sheep nutrient requirements. However, variations in production levels resulting from the physiological trend of the lactation curve are not always associated with corresponding intake changes. The present study demonstrates how dry matter and crude protein intake numerically changed during pregnancy and lactation periods. During late pregnancy, the level of these parameters is much higher than during early pregnancy and then during lactation this level falls again. The present results also showed that both MPP and MPL treatments possessed a significant effect on productivity, reproductive performance and metabolic profiles of Barki ewes. The results obtained concerning the utilization of dry matter and other nutrients in groups with MPP and MPL were in agreement with those reported by Saleem et al. (2017) who obtained that dry matter intake nutrients digestibility of lambs were positively influenced by adding different levels of probiotics supplementation. Also, Gomaa et al. (2016) found that treated rice straw by bacterial enzymes (MPL) led to improve total digestible nutrient, digested crude protein and nitrogen balance of sheep. Gado et al. (2007) showed that the MPP enzyme product improved in vitro dry matter digestibility of wheat straw in the first $24 \mathrm{~h}$ of incubation. The MPL and MPP forms were rich in xylanolytic, cellulose, $\alpha$-amylase and protease activity, has positive effects on digestion. In the present study, increasing total feed intake may be due to the increase in body weight during different physiological stages. Kholif et al. (2017) suggested that ration supplemented by 4 gram fibrolytic enzyme per head per day showed insignificant raised for live body weight. Generally, total feed intake in all groups covered nutrient requirements of ewes according to physiological status and under desert conditions.

Ewes' body weight varied throughout the year and it changes with stage of production. In this regard, physiological stages (pregnancy, lactation ...) greatly influence the body weight of ewes. In general, the ewes during the period of early lactation have lower body weight than the other periods and maximum weight was observed in the period of late pregnancy. Body weight changes from initial weight in early and late lactation period showed an increase in MPL and MPP groups compared to the control group. These results indicated that rations supplemented with biological additives (i.e., MPL and MPP) have positive effects on body weight changes during different physiological stages. Sabbah et al. (2009) and Helal et al. (2018a) suggested that higher Crude Protein (CP) digestibility and dry matter intake led to increase in body weights in Shami goats fed diets supplemented with MPL and MPP probiotic. Gado et al. (2009) reported that an exogenous enzyme of MPP has been shown to have marked positive effects on increasing the total microbial population in the rumen and increased microbial protein synthesis in sheep. However, they found that supplemental enzymes had no effects on nutrient intakes or growth performance of lambs in term of growth rate, final body weight and total gain. The present study clarifies that ewes fed on poor quality roughage and improved rumen ecosystem by feed additives for instance exogenous enzymes gives the best results with the promise animals.

Table 2. Effect of probiotic treatments on feed intake of Barki ewes during pregnancy and lactation periods

\begin{tabular}{|c|c|c|c|c|c|c|c|}
\hline Items & G1 & G2 & G3 & G4 & G5 & SEM & P value \\
\hline \multicolumn{8}{|c|}{ Dry matter intake during early pregnancy } \\
\hline Average BW (kg) & 37.0 & 36.7 & 36.4 & 38.8 & 38.3 & 0.586 & 0.625 \\
\hline Roughage (g/h/d) & 638 & 633 & 628 & 670 & 661 & 10.11 & 0.423 \\
\hline $\mathrm{CFM}(\mathrm{g} / \mathrm{h} / \mathrm{d})$ & 425 & 422 & 418 & 446 & 441 & 6.741 & 0.233 \\
\hline Total $(\mathrm{g} / \mathrm{h} / \mathrm{d})$ & 1063 & 1055 & 1046 & 1116 & 1102 & 16.85 & 0.133 \\
\hline Total CPI (g/h/d) & 93.8 & 93.1 & 92.3 & 98.5 & 97.3 & 1.487 & 0.333 \\
\hline $\mathrm{R}: \mathrm{C}$ ratio & $60: 40$ & $60: 40$ & $60: 40$ & $60: 40$ & $60: 40$ & - & - \\
\hline \multicolumn{8}{|c|}{ Dry matter intake during late pregnancy } \\
\hline Average BW (kg) & 40.9 & 40.8 & 41.6 & 42.6 & 42.4 & 0.616 & 0.859 \\
\hline Roughage (g/h/d) & 606 & 604 & 616 & 630 & 628 & 9.124 & 0.234 \\
\hline $\mathrm{CFM}(\mathrm{g} / \mathrm{h} / \mathrm{d})$ & 909 & 906 & 923 & 945 & 941 & 13.68 & 0.416 \\
\hline Total $(\mathrm{g} / \mathrm{h} / \mathrm{d})$ & 1515 & 1510 & 1539 & 1575 & 1569 & 22.81 & 0.128 \\
\hline Total CPI (g/h/d) & 151.6 & 151.0 & 153.9 & 157.6 & 156.9 & 0.228 & 0.614 \\
\hline $\mathrm{R}: \mathrm{C}$ ratio & $60: 40$ & $60: 40$ & $60: 40$ & $60: 40$ & $60: 40$ & - & - \\
\hline \multicolumn{8}{|c|}{ Dry matter intake during early lactation } \\
\hline Average BW (kg) & 35.3 & 35.6 & 36.0 & 38.8 & 38.0 & 0.532 & 0.258 \\
\hline Roughage (g/h/d) & 885 & 892 & 903 & 959 & 951 & 13.31 & 0.124 \\
\hline $\mathrm{CFM}(\mathrm{g} / \mathrm{h} / \mathrm{d})$ & 590 & 595 & 602 & 640 & 634 & 8.874 & 0.331 \\
\hline Total $(\mathrm{g} / \mathrm{h} / \mathrm{d})$ & 1475 & 1487 & 1505 & 1599 & 1585 & 22.18 & 0.422 \\
\hline Total CPI (g/h/d) & 130.1 & 131.2 & 132.8 & 141.1 & 139.9 & 1.957 & 0.341 \\
\hline $\mathrm{R}: \mathrm{C}$ ratio & $40: 60$ & $40: 60$ & $40: 60$ & $40: 60$ & $40: 60$ & - & - \\
\hline \multicolumn{8}{|c|}{ Dry matter intake during late lactation } \\
\hline Average BW (kg) & 36.1 & 36.9 & 37.1 & 39.1 & 39.2 & 0.539 & 0.242 \\
\hline Roughage (g/h/d) & 800 & 818 & 823 & 869 & 871 & 11.98 & 0.151 \\
\hline CFM $(\mathrm{g} / \mathrm{h} / \mathrm{d})$ & 534 & 545 & 549 & 579 & 580 & 7.986 & 0.534 \\
\hline Total $(\mathrm{g} / \mathrm{h} / \mathrm{d})$ & 1334 & 1364 & 1371 & 1448 & 1451 & 19.96 & 0.452 \\
\hline Total CPI (g/h/d) & 117.7 & 120.3 & 121.0 & 127.8 & 128.0 & 1.762 & 0.641 \\
\hline $\mathrm{R}: \mathrm{C}$ ratio & $40: 60$ & $40: 60$ & $40: 60$ & $40: 60$ & $40: 60$ & - & - \\
\hline
\end{tabular}

G1: the control concentrate ration; G2: concentrate ration with $6 \mathrm{~g}$ mixture probiotic powder (MPP) /h/d; G3: concentrate ration with 10 g MPP /h/d; G4: concentrate ration with $6 \mathrm{ml}$ mixture probiotic liquid (MPL) /h/d; G5: concentrate ration with $10 \mathrm{ml} \mathrm{MPL} / \mathrm{h} / \mathrm{d}$; BW: body weight; g/h/d: gram per head per day; CFM: concentrate feed mixture; BS: bean straw; CPI: crude protein intake; R:C ratio: roughage to concentrate ratio. 
Table 3. Effect of probiotic treatments on live body weight changes of Barki ewes during pregnancy and lactation periods

\begin{tabular}{lccccccc}
\hline Items & G1 & G2 & G3 & G4 & G5 & SEM & P value \\
\hline IBW & 34.9 & 33.4 & 33.1 & 35.0 & 35.0 & 1.31 & 0.882 \\
Early pregnancy weight & 37.0 & 36.7 & 36.4 & 38.8 & 38.3 & 1.33 & 0.633 \\
BW changed from IBW & $2.03^{\mathrm{a}}$ & $2.96^{\mathrm{b}}$ & $2.68^{\mathrm{ab}}$ & $3.85^{\mathrm{c}}$ & $3.36^{\mathrm{bc}}$ & 0.208 & $<0.001$ \\
Late pregnancy weight & 40.9 & 40.8 & 41.6 & 42.6 & 42.4 & 1.41 & 0.857 \\
BW changes from IBW & $6.00^{\mathrm{a}}$ & $7.07^{\mathrm{ab}}$ & $7.88^{\mathrm{b}}$ & $7.60^{\mathrm{ab}}$ & $7.44^{\mathrm{ab}}$ & 0.462 & 0.037 \\
Early lactation weight & 35.3 & 35.6 & 36.0 & 38.3 & 38.0 & 1.22 & 0.258 \\
BW changes from IBW & $0.37^{\mathrm{a}}$ & $1.88^{\mathrm{ab}}$ & $2.32^{\mathrm{b}}$ & $3.33^{\mathrm{b}}$ & $3.00^{\mathrm{b}}$ & 0.441 & $<0.001$ \\
Late lactation weight & 36.1 & 36.9 & 37.1 & 39.1 & 39.2 & 1.24 & 0.242 \\
BW changes from IBW & $1.12^{\mathrm{a}}$ & $3.12^{\mathrm{b}}$ & $3.35^{\mathrm{b}}$ & $4.17^{\mathrm{b}}$ & $4.25^{\mathrm{b}}$ & 0.437 & $<0.001$ \\
\hline G1: & & &
\end{tabular}

G1: the control concentrate ration; G2: concentrate ration with $6 \mathrm{~g}$ mixture probiotic powder (MPP) /h/d; G3: concentrate ration with 10 g MPP /h/d; G4: concentrate ration with $6 \mathrm{ml}$ mixture probiotic liquid (MPL) /h/d; G5: concentrate ration with $10 \mathrm{ml}$ MPL /h/d; BW: body weight (kg); IBW: initial body weight; Different superscripts $(a, b, c)$ within each row indicate significance $(\mathrm{P}<0.05)$.

\section{Reproductive performance of Barki ewes}

There were no significant differences $(\mathrm{P}<0.05)$ between the studied ewe groups in the measured reproductive parameters. Only in case of a few reproductive parameters such mortality, abortion rate (\% of pregnancies), $\%$ of conception rate and $\%$ of lambing rate. Addition of studied enzymes decreased $(\mathrm{P}<0.05)$ mortality rate from birth to weaning $(5.3-5.6 \%)$ compared to control group, where it was much higher (11.8\%). The G4 group with $6 \mathrm{ml} / \mathrm{h} / \mathrm{d}$ MPL showed the lowest values of conception rate, number of ewes lambed, lambing rate and number of born alive lambs. In this group, no lamb mortality was founded compared with other experimental groups (Table 4).

Table 4. Effect of probiotic treatments on reproductive performance of Barki ewes in the North Western Coast of Egypt

\begin{tabular}{|c|c|c|c|c|c|c|}
\hline Reproductive performance & Items & G2 & G3 & G4 & G5 & $P$ value \\
\hline Number of ewes joined & 20 & 20 & 20 & 20 & 20 & \\
\hline Number of ewes conceived & 18 & 19 & 19 & 17 & 19 & \\
\hline Conception rate $(\%)$ & 90 & 95 & 95 & 85 & 95 & 0.732 \\
\hline Number of ewes aborted & 0 & 1 & 0 & 1 & 0 & \\
\hline Abortion rate (\% of pregnant) & 0 & 5.3 & 0 & 5.9 & 0 & 0.430 \\
\hline Number of still births & 1 & 0 & 1 & 1 & 1 & 0.763 \\
\hline Number of ewes lambed & 17 & 18 & 18 & 15 & 18 & \\
\hline Lambing rate $(\%)$ & 85 & 90 & 90 & 75 & 90 & 0.630 \\
\hline Number of lamb born alive & 17 & 19 & 18 & 16 & 18 & \\
\hline Number of lamb weaned & 15 & 18 & 17 & 16 & 17 & \\
\hline Lamb mortality (\%) & 11.8 & 5.3 & 5.6 & 0.0 & 5.6 & 0.593 \\
\hline
\end{tabular}

In sheep production, reproductive performance is a feature of great importance especially when the meat production from small animals is the main objective. In general, the more demanding the meat production system, the more needed the production of large numbers of the offspring per breeding female. In terms of reproductive wastage, lamb losses represent a serious problem because all investments made for ewes to conceive and maintain pregnancy are wasted. In this study, 100 ewes were joined in mating season, eight ewes from 100 were barren (two in G1, one in G2, one in G3, three in G4 and one in G5). However, supplementations of MPL and MPP enzymes have positive effects on the health condition of ewes and their lambs (Table 4). The same results obtained by Abdalla et al. (2012) who found that reproductive parameters were increased in Ossimi ewes fed diet supplemented with MPP $(15 \mathrm{~g} / \mathrm{h} / \mathrm{d})$ or fed diet supplemented with melatonin $(3 \mathrm{mg} / \mathrm{h} / \mathrm{d})$ MPP plus $(15 \mathrm{~g} / \mathrm{h} / \mathrm{d})$ compared to the control group. In a study of Abo-Bakr (2012), goats fed diet with MPL (one L/ton wheat straw) showed a high percentage of conception and kidding rats, while goats fed diet with MPP $(20 \mathrm{~g} / \mathrm{h} / \mathrm{d})$ showed the lowest percentage of conception rate compared to the control group. The MPP and the control group recorded the same percentage of kidding rate (80\%). They also found that the control group recorded the highest mortality rate from birth to weaning (28.6\%), while MPL and MPP treated groups recorded 15.8 and $16.7 \%$, respectively, which support the present results.

However, conception is the point in time when the sperm fertilizes the ova and the conception rate is usually considered to be the number of ewes that lambed compared to the number of ewes joined. Using this broad definition of conception rate, more factors can influence the results, because both fertility and embryo loss can be included in the outcome. Conception rates in the present study were the highest among ewes that had addition of biological probiotics, except one group (G4 - $6 \mathrm{ml} / \mathrm{h} / \mathrm{d}$ of MPL) compared to the other treatments. Abortions in ewes are the result of many factors that stress the pregnant animal. Intrauterine infections are the most common cause. It appears normal for about 
1.5 to $2.0 \%$ (up to $5 \%$ ) of the ewes in a flock to abort. Many farmers accept abortion rates of between $5-10 \%$. In the present experiment, this parameter ranged between 0.0 and 5.9. Percentage of lambing is still the main important factor in determining profit and even a small improvement will increase the income. Low lambing rates represent a major obstacle to the sheep industry. Regardless of G4, the highest lambing rate was in the case of ewe fed with MPL and MPP. The number of new born lambs per ewe joined is certainly an economically important trait in a commercial sheep initiative. Lamb mortality occurs in any flock, because there are so many reasons affect survival rate of lambs, it is difficult to determine the causes that could affect lamb survival in the flock. Many factors influence and potentially cause problems in these areas - nutrition of the ewe during gestation, sanitation, ventilation, size of litter and birth weight. In the treatment group of the present study, the lamb mortality was around 5\%. It was much less than that of the control group.

\section{Birth and weaning weights of Barki lambs}

Birth, weaning weights and average daily gain were increased $(\mathrm{P}<0.05)$ in all treated groups. G4 and G5 groups recorded the best $(\mathrm{P}<0.05)$ birth weights with values being 3.19 and $3.33 \mathrm{~kg}$ for $\mathrm{G} 4$ and $\mathrm{G} 5$, respectively, weaning weight (22.0 and $22.0 \mathrm{~kg}$ ) and average daily gain was 209 and $207 \mathrm{~g}$, respectively. The weaning weight was on the same level, regardless of the amount of additive of MPP and MPL. The same result was observed by Saleem and Zanouny (2016) as they noted that addition of different level ( 0.5 or $1 \mathrm{gram} / \mathrm{head} /$ day) of probiotic led to insignificant increase of daily gain for weaned lambs. The obtained results showed that the larger addition of biological enzymes slightly decreased $(\mathrm{P}<0.05)$ average daily gain (Table 5). The lamb weight of at birth has a great impact on the ability of the lamb to survive. Nutrition of the ewe at the end of gestation and the number of lambs per ewe are the two main factors affecting the weight of the lambs. In addition, the present results showed that higher value of lamb birth weight, weaning weight and average daily gain were recorded in MPL and MPP groups in compared to the control group. Improvement of average daily gain and weaning weight in treated groups are probably due to increased ruminal fermentation activities and nutrient digestion (Gado et al., 2011), improve synthesis of microbial protein that resulted in increased post-ruminal amino acids supply (El-Katch et al., 2016) or may be due to the highest milk production for their mothers. Thakur et al. (2010) investigated the effect of supplementing exogenous enzymes on the growth performance in buffalo calves. They reported that high dose of enzymes enhanced the average body weight and average daily gain. In Previous study carried out by Titi and Lubbadeh (2004), the influence of fibrolytic enzyme treatment on birth and weaning weights of Awassi lambs and Shami kids was investigated. They found that there were no significant differences in average birth weight between control and enzyme treated groups for both lambs and kids. However, weaning weight of lambs from ewes fed enzyme supplementation diets were higher $(\mathrm{P}<0.05)$ than those of the control group, while no differences were observed between treated and control groups in weaning weights of kids. Probiotic is usually related to stimulation of cellulolytic and lactate-utilizing bacteria in the rumen, increased fiber digestion, and increased flow of microbial protein from the rumen which may be beneficial for lambs live weight (Salem et al., 2004). On the other hand, Bueno et al. (2013) evaluated the effect of high doses of exogenous enzymes on lamb performance, and doses were $0,5,10 \mathrm{~g}$ of enzymes per one $\mathrm{kg}$ oat straw. They reported that increasing enzyme doses resulted in decreasing enzyme treatment intake without changing the weight gain of lambs.

Table 5. Effect of probiotic treatments on productive performance of Barki lambs in the North Western Coast of Egypt

\begin{tabular}{lccccccc}
\hline Traits & G1 & G2 & G3 & G4 & G5 & SEM & P value \\
\hline Birth weight $(\mathrm{Kg})$ & $2.88^{\mathrm{a}}$ & $3.04^{\mathrm{ab}}$ & $3.17^{\mathrm{ab}}$ & $3.19^{\mathrm{ab}}$ & $3.33^{\mathrm{b}}$ & 0.094 & 0.012 \\
Weaning weight, $(\mathrm{Kg})$ & $20.0^{\mathrm{a}}$ & $21.5^{\mathrm{b}}$ & $21.5^{\mathrm{b}}$ & $22.0^{\mathrm{b}}$ & $22.0^{\mathrm{b}}$ & 0.39 & 0.002 \\
Average daily gain, $(\mathrm{Kg})$ & $0.190^{\mathrm{a}}$ & $0.205^{\mathrm{b}}$ & $0.203^{\mathrm{ab}}$ & $0.209^{\mathrm{b}}$ & $0.207^{\mathrm{b}}$ & 0.0041 & 0.008 \\
\hline G1 & & &
\end{tabular}

G1: the control concentrate ration; G2: concentrate ration with $6 \mathrm{~g}$ mixture probiotic powder (MPP) $/ \mathrm{h} / \mathrm{d}$; G3: concentrate ration with $10 \mathrm{~g}$ MPP $/ \mathrm{h} / \mathrm{d}$; G4: concentrate ration with $6 \mathrm{ml}$ mixture probiotic liquid (MPL) /h/d; G5: concentrate ration with $10 \mathrm{ml} \mathrm{MPL} / \mathrm{h} / \mathrm{d}$; Different superscripts (a, b, c) within each row indicate significance $(\mathrm{P}<0.05)$.

\section{Thyroid hormones}

Concerning thyroid activity, G3 group (10g/h/d MPP) recorded the highest $(\mathrm{P}<0.05)$ value of $\mathrm{T}_{3}(1.72 \mathrm{ug} / \mathrm{dl})$, while G5 group $\left(10 \mathrm{ml} / \mathrm{h} / \mathrm{d}\right.$ MPL) recorded the highest $(\mathrm{P}<0.05)$ value of $\mathrm{T}_{4}(7.34 \mathrm{ug} / \mathrm{dl})$. Moreover, all treated groups had higher $(\mathrm{P}<0.05)$ values of two thyroid hormones than the control group (Table 6). Thyroid hormones, which are mainly function in the regulation of tissue growth and metabolism, are affected by many factors including nutrition (Baruah et al., 1993). Many studies reported a marked seasonal variation in thyroid activity and in blood thyroid hormone concentration (Chavhan and Dhamani, 2013; Dardente et al., 2014 and Qasim et al., 2018). These hormonal differences in free and grazing animals are particularly important that major physiological functions (feed intake, reproduction and hair growth) are outstandingly seasonal. This is the situation with the traditional breeding of small ruminants. In fact, such differences in hormone concentrations allow animals to adjust their metabolic balance with different environmental 
conditions, differences in nutrient requirements and availability, and to homeoretic changes during different physiological stages (Ganong, 1995). Data of the present study showed that thyroid hormones $\left(\mathrm{T}_{3}\right.$ and $\left.\mathrm{T}_{4}\right)$ were tended to increase in groups fed rations supplemented with MPL and MPP. Groups 3 and 5 recorded the highest values of $\mathrm{T}_{3}$ and $\mathrm{T}_{4}$ hormones, while the control group recorded the lowest values of thyroid hormones. Animals fed rations supplemented with the level of $6 \mathrm{~g}$ or $\mathrm{ml}$ from MPL and MPP showed nearly concentrations of $\mathrm{T}_{3}$ and $\mathrm{T}_{4}$ hormones that revealed by control group. The increase in thyroid hormones in ewes fed ration supplemented with probiotic mixture as compared to the control group indicated that these probiotics may be due to the increased protein level, improve dry matter and other nutrient digestibility (Gado et al., 2009). Mohamed and Abou-Zeina (2008) who found that $\mathrm{T}_{3}$ and $\mathrm{T}_{4}$ concentration were higher in goats fed diets supplemented with high doses of exogenous enzyme compared to the low level and the control group. They suggested that the enzymes directly or indirectly promoted an enhanced activity of deiodinase in liver and kidney tissues, promoting the transformation of $\mathrm{T}_{4}$ into the biologically active hormone $\left(\mathrm{T}_{3}\right)$.

Table 6. Effect of probiotic treatments on thyroid hormones concentrations of Barki ewes in the North Western Coast of Egypt

\begin{tabular}{lccccccc}
\hline Thyroid hormone & G1 & G2 & G3 & G4 & G5 & SEM & P value \\
\hline $\mathrm{T}_{3}(\mathrm{ng} / \mathrm{ml})$ & 1.57 & 1.58 & 1.72 & 1.60 & 1.63 & 0.054 & 0.327 \\
$\mathrm{~T}_{4}(\mu \mathrm{g} / \mathrm{ml})$ & 7.01 & 7.05 & 7.29 & 7.20 & 7.34 & 0.263 & 0.873 \\
\hline
\end{tabular}

G1: the control concentrate ration; G2: concentrate ration with $6 \mathrm{~g}$ mixture probiotic powder (MPP)/h/d; G3: concentrate ration with $10 \mathrm{~g}$ MPP /h/d; G4: concentrate ration with $6 \mathrm{ml}$ mixture probiotic liquid (MPL) /h/d; G5: concentrate ration with $10 \mathrm{ml} \mathrm{MPL} / \mathrm{h} / \mathrm{d}$.

\section{Milk yield and composition}

The present treatments tended to increase $(\mathrm{P}<0.05)$ the total milk yield of all treated ewe groups. The best results in this case were observed in MPP (G2 and G3). Milk yield increased $(\mathrm{P}<0.05)$ with the supplementation of probiotic during the early, mid and late of lactation period. These results agreed with Refat et al. (2018) who reported that pretreating dairy cows' rations with fibrolytic enzyme led to increase milk production. However, the value of milk composition was the highest in G4 group ( $6 \mathrm{ml} / \mathrm{h} / \mathrm{d}$ MPL). Other treatment groups were lower in comparison with the control group (Table 7). Supplementation of probiotic preparation (i.e., MPP or MPP) did not affect $(\mathrm{P}<0.05)$ the total milk yield but it improved $(\mathrm{P}<0.05)$ the milk yield during the early, mid and late of the lactation stages. The improvement $(\mathrm{P}<0.05)$ was in MPP supplemented groups for G2 and G3, respectively, followed by MPL supplemented groups for G4 and G5, respectively, while milk production in the control group recorded the lowest value. The present study showed that treated groups $(\mathrm{P}<0.05)$ increased in milk production in early and mid-lactation stages as compared to the control group. Mid lactation recorded high milk production followed by the early stage, while late stages recorded the lowest values in all groups. These results are in agreement with those reported by Titi and Lubbadeh (2004) who found that milk production was increased $(\mathrm{P}<0.05)$ by $10-12 \%$ affected by the enzyme supplementation in Awassi ewes and Shami goats. They suggested that the improved milk production in ewes and goats could be attributed to the increase total tract dry matter digestibility. Moreover, the improvement of milk production by exogenous enzyme supplementation for dairy cows fed alfalfa hay or total mixed ration was a direct result of increased feed digestibility rather than to increased feed intake and energy available for milk production (Yang et al., 2000).

Table 7. Effect of probiotic treatments on ewes milk yield and milk composition (\%) during lactation period (12 weeks)

\begin{tabular}{lccccccc}
\hline Traits & G1 & G2 & G3 & G4 & G5 & SEM & P- \\
\hline Milk yield (ml/h/d) & 510 & 584 & 599 & 543 & 556 & 34.12 & 0.575 \\
Early (ml/h/d) & $502^{\mathrm{a}}$ & $604^{\mathrm{b}}$ & $639^{\mathrm{b}}$ & $550^{\mathrm{ab}}$ & $577^{\mathrm{b}}$ & 28.16 & 0.001 \\
Mid (ml/h/d) & $537^{\mathrm{a}}$ & $646^{\mathrm{b}}$ & $634^{\mathrm{b}}$ & $582^{\mathrm{b}}$ & $594^{\mathrm{b}}$ & 25.02 & 0.001 \\
Late (ml/h/d) & $492^{\mathrm{a}}$ & $504^{\mathrm{b}}$ & $524^{\mathrm{b}}$ & $499^{\mathrm{b}}$ & $499^{\mathrm{b}}$ & 22.04 & 0.001 \\
Milk composition & & & & & & \\
Fat (\%) & $3.98^{\mathrm{a}}$ & $3.40^{\mathrm{ab}}$ & $3.52^{\mathrm{ab}}$ & $3.96^{\mathrm{a}}$ & $3.25^{\mathrm{a}}$ & 0.212 & 0.055 \\
Protein (\%) & 3.77 & 3.68 & 3.75 & 3.90 & 3.84 & 0.132 & 0.798 \\
Lactose (\%) & 5.02 & 5.03 & 5.06 & 5.09 & 5.06 & 0.046 & 0.823 \\
Total solids (\%) & 13.53 & 12.85 & 13.08 & 13.78 & 12.97 & 0.279 & 0.105 \\
Ash (\%) & $0.76^{\mathrm{b}}$ & $0.74^{\mathrm{b}}$ & $0.75^{\mathrm{b}}$ & $0.83^{\mathrm{a}}$ & $0.82^{\mathrm{a}}$ & 0.011 & $<0.001$ \\
\hline
\end{tabular}

G1: the control concentrate ration; G2: concentrate ration with $6 \mathrm{~g}$ mixture probiotic powder (MPP) /h/d; G3: concentrate ration with $10 \mathrm{~g}$ MPP /h/d; G4: concentrate ration with $6 \mathrm{ml}$ mixture probiotic liquid (MPL) /h/d; G5: concentrate ration with $10 \mathrm{ml} \mathrm{MPL} / \mathrm{h} / \mathrm{d} ; \mathrm{ml} / \mathrm{h} / \mathrm{d}$ : millilitre per head per day; Different superscripts $(\mathrm{a}, \mathrm{b}, \mathrm{c})$ in a row indicate significance $(\mathrm{P}<0.05)$.

Moreover, Morsy et al. (2016) reported that milk production was increased in Egyptian buffaloes fed diets supplemented with Veta-Zyme plus or Tomoko enzyme product. Gado et al. (2009) found that milk production was higher in enzyme supplemented cows compared to control cows $(12.75 \mathrm{vs} .15 .70 \mathrm{~kg} / \mathrm{h} / \mathrm{d})$ for control and supplemented group. In Shami goats, Abo Bakr (2012) found that milk yield was higher in goats fed wheat straw treated with MPL solution $(1.07 \mathrm{~L} / \mathrm{h} / \mathrm{d})$ followed by goats fed wheat straw treated by $3 \%$ molasses plus $3 \%$ urea and added $20 \mathrm{~g} / \mathrm{h} / \mathrm{d}$ of MPP . Also, he reported that there is insignificant increase in milk production between two groups fed rations 
supplemented with two forms of enzymes (liquid versus powder) compared with control group. Also in this study explained that the increase in milk production might be due to higher nutrient digestibility and more effects on manipulation of rumen environment which lead to more feed efficiency and more productivity. In contrast, Dean et al. (2007) revealed that enzyme supplementation did not improve in vivo digestibility of lactating cows, therefore milk production was not significantly affected. Flores et al. (2008) found that no effects on lactation when fibrolytic enzyme product was added to the concentrate of dairy ewes. Milk protein was higher in treated groups but differences were not significant. While milk fat tended to increase in control and G4 groups compared to other groups. While, milk lactose and total solids were not affected by treatments. The higher milk components of probiotic treated ewes than the control group were most likely due to more availability of nutrients as a result of improved digestibility following enzyme treatment (Yang et al., 2000). In contrary, Rode et al. (1999) found a drop in milk fat and protein of dairy cows fed fibrolytic enzymes treated diet. Sabbah et al. (2009) reported that milk protein was increased in MPL and MPP treated diets compared to the untreated group, while other compounds (fat, lactose, total solids and solid not fat) were not affected. The higher milk protein content by probiotic supplementation may be due to stimulation of rumen microbes that cause altering in microbial protein synthesis and increase protein yield in the milk (Dawson, 1993).

\section{Feed efficiency and economical evaluation of ewes during lactation period}

Feed efficiency, feed conversion and economical evaluation are presented in table 8 . The best feed conversion in term of Kg DM intake/one litter milk was in G3 and G2 (Rations supplemented with MPP). This may be due to its higher milk production. These results were agreed with those obtained by Abo Bakr (2012) who found that goats fed biologically treated straw showed better feed efficiency than control group. Moreover, Kewan et al. (2019) suggested that treated Moringa oleifera tree stalks by different type of probiotic (fungi or yeast) had better economical feed efficiency compared to the control group. Also, G2 was better for Kg DMI / Kg weaned live body weight followed by G3while the worst recorded by G1 (control group). This may be due to variation in milk yield which higher for G2 and G3 (Table 7). In the same trend, the low cost to produce one litter milk recorded by G2. While, the high cost of production (gain or milk) recorded by G4 and G5 because the high price of MPL and milk production did not cover this cost. On behave of the cost to produce one $\mathrm{kg}$ gain, the lowest cost was in G1 because did not supplemented with any additives while, the highest cost recorded by G5 supplemented with high dosage of MPL and expensive price of it. Differences between the price of feed additives plus and the price of live body weight $(\mathrm{Kg})$ as return from selling weaning kids showed G2 was higher income followed by G3 and G4 while lower income recorded by G5 and G1 respectively. The differences in additives dosages, price of additives, daily and total gain led to this results. Generally, feed efficiency for ewes fed biologically additives (especially MPP) was better than those fed control rations and other groups. The same result was obtained by Abd El-Ghani and Metawli (2003) suggested biologically treated roughage improved feed efficiency (DM intake/milk).

Table 8. Effect of probiotic treatments on feed efficiency and economical evaluation of ewes during lactation periods

\begin{tabular}{lccccc}
\hline Items & G1 & G2 & G3 & G4 & G5 \\
\hline Feed efficiency & & & & & \\
Kg DMI/litter milk & 2.75 & 2.44 & 2.40 & 2.80 & 2.73 \\
Suckling milk / kg gain & 2.69 & 2.85 & 2.95 & 2.60 & 2.69 \\
Kg DMI / Kg weaned live body weight & 16.16 & 15.11 & 15.24 & 15.65 & 15.56 \\
Feed cost LE/h/d & & & & \\
Roughage cost & 1.69 & 1.71 & 1.73 & 1.83 & 1.82 \\
CFM cost & 2.25 & 2.28 & 2.30 & 2.44 & 2.43 \\
MPP cost & 0 & 0.45 & 0.75 & 0 & 0 \\
MPL cost & 0 & 0 & 0 & 0.9 & 1.5 \\
Total cost & 3.94 & 4.44 & 4.78 & 5.17 & 5.75 \\
Feed cost / litter milk & 7.71 & 7.59 & 7.98 & 9.50 & 10.33 \\
Feed cost / kg gain & 20.70 & 21.66 & 23.54 & 24.72 & 27.78 \\
Cost of total gain & 354.38 & 399.82 & 431.43 & 464.94 & 518.61 \\
Price of total gain & 1198.4 & 1292.2 & 1283.1 & 1316.7 & 1306.9 \\
Return from selling & 844.02 & 892.38 & 851.67 & 851.76 & 788.29 \\
\hline
\end{tabular}

G1: the control concentrate ration; G2: concentrate ration with 6 g mixture probiotic powder (MPP) /h/d; G3: concentrate ration with 10 g MPP /h/d; G4: concentrate ration with $6 \mathrm{ml}$ mixture probiotic liquid (MPL) /h/d; G5: concentrate ration with $10 \mathrm{ml}$ MPL /h/d; CFM: concentrate feed mixture; BS: bean straw; DMI: dry matter intake; LE: Egyptian pound; Price of ton CFM = $4000 \mathrm{LE}$; price of ton Bean straw = 2000 LE; Price of litter MPL = $150 \mathrm{LE}$; price of $\mathrm{Kg} \mathrm{MPP}=75 \mathrm{LE}$; price of $\mathrm{kg}$ live body weight $=70 \mathrm{LE}$.

\section{CONCLUSION}

The novel of this study was the evaluation of the impact of two forms of probiotic preparations, as sources of exogenous enzymes, on some productive and physiological reproductive parameters in ewes during different physiological stages of pregnancy and lactation. However, the results provided quantitative information about the impact of MPL and MPP 
enzymes on utilization of feed intake, live body weight, reproductive performance, daily gain, milk yield and composition, feed efficiency and thyroid hormones in Barki ewes. The best treatment was the MPL $6 \mathrm{ml} / \mathrm{h} / \mathrm{d}$, which improved the productive and reproductive parameters. While, the best feed efficiency and economical evaluation recorded by G2 (MPP). Generally, all groups fed biologically treated rations showed positive effect in all parameters compared with control group. Based on these results, it was concluded that the probiotic mixture preparations (MPL and MPP), sourced from anaerobic bacterium and added to sheep rations, increased utilization of feed intake and body weight changes during pregnancy and lactation stages. In addition, probiotic mixture improved the weaning weight, daily gain of lambs, live body weight changes of ewes and milk production. The present study indicated that both MPP and MPL treatments possessed a significant effect on productivity, reproductive performance and metabolic profile of Barki ewes.

\section{DECLARATIONS}

\section{Acknowledgments}

The authors are thankful to Dr. Hamdy Gawish for facilitating the research work at the Sustainable Development Center for Matrouh Resources. We also would like to appreciate all participants who contributed during sample collection.

\section{Competing interests}

The authors declare that they have no conflict of interest with respect to the research, authorship, and/or publications of this article. The authors declare that they have no competing interests.

\section{Author's contribution}

Dr. Ahmed Sobhy El-Hawy designed the experiment, article writing and revision. Dr. Moharram Fouad ElBassiony designed the experiment, statistical analysis, tabulation of experimental data, manuscript writing, commenting and approval. Dr. Salah Abo Bakr helped in field study, collected data, tabulation of experimental data and article writing. Dr. Hamdi Abdel-Aziz Gawish facilitates the field study, manuscript writing and revision. Dr. Mohamed Tarek Badawy facilitates the field study. While, Dr. Hany Mohamed Gado, provides the probiotic mixtures, designed the experiment, manuscript writing. All authors have read and approved the final manuscript.

\section{REFERENCES}

Abd El-Ghani AA and Metawli AA (2003). Effect of leucaena leucocephala silage treated with different levels of Lactic acid bacteria on performance of Ossimi ewes. Egyptian Journal of Nutrition and feeds, 6 (Special Issue): 833-842.

Abdalla EB, Al-Momani AQ, Khalil FA, Gado HM and Al-Barakeh FS (2012). Improving reproductive performance of Ossimi ewes using hormonal and enzymatic treatments. Dairy Science, 95(2): 71.

Abdalla EB, El-Hawy AS, Gawish HA and Madany EM (2015). Reproductive and productive efficiency of Barki ewes fed on Nigella Sativa as a source of ration protein. Egyptian Journal of Nutrition and feeds, 18(2): 213-221.

Abo-Bakr S (2012). Nutritional studies on goats fed treated straw under North Sinai conditions. Ph. D. Thesis, Faculty of Agriculture, Cairo University, Egypt, pp. 49-93.

Adams RS, Moore JH, Kesler EM and Stevens GZ (1964). New relationships for estimating TDN content of forages from chemical composition. Journal of Dairy Science, 47: 1461. Agriculture (27): 436-441.

AOAC (1990). Official Methods of Analysis. Association of official analytical chemists international, 16th Edition, Vol. 1, Agricultural, chemicals, contaminants Drugs Washington DC, USA.

Aziz HAA (2009). Effect of feeding olive tree pruning by-products in Sinai on sheep performance, Ph. D. Thesis, Faculty of Agriculture, Ain Shams University, Egypt, pp. 51-89.

Baruah KK, Baruah A, Baruah RN and Zaman J (1993). Relation of serum thyroxin and triiodothyronin to body weight in kid. Indian Veterinary Journal, 1: 118-1121.

Beauchemin KA, Rode LM, Macaw M, Morgan DP and Kampent R (2000). Evaluation of a nonstarch polysaccharidase feed enzyme in dairy cow diets. Journal of Dairy Science, 83: 543. DOI: https://doi.org/10.3168/jds.S0022-0302(00)74914-9.

Bueno AL, Martinez GM, Garcia PH, Garcia JM and Perez FP (2013). Evaluation of high doses of exogenous fibrolytic enzymes in lambs fed oat straw based ration. Animal Nutrition and Feed Technology, 13: 355-362. https://www.researchgate.net/publication/290225972.

Chavhan P and Dhamani A (2013). Seasonal Variation in Thyroid Gland of the Female Bat, Taphozous Kachhensis (Dobson) During Pregnancy. International Journal of Molecular Zoology, 13(2): 4-9. DOI: http://dx.doi.org/10.5376/ijmz.2013.03.0002

Dardente H, Hazlerigg DG and Ebling FJP (2014). Thyroid Hormone and Seasonal Rhythmicity. Frontiers in Endocrinology, 5(19): 111. DOI: https://doi.org/10.3389/fendo.2014.00019

Dawson KA (1993). Biotechnology in the feed industry. Proceedings of All tech's, 9th Annual Symposium, 269.

Dean DB, Adesogan AT, Staples CR, Littell RC and Kim SC (2007). Effect of method of adding a fibrolytic enzyme to different components of a dairy caw diet on feed intake, digestibility, milk production, ruminanl, fermentation and blood metabolites. Animal Nutrition and Feed Technology, 13: 337-353.

Duncan DB (1955). Multiple range and multiple f tests. Biometrics, 11: 1-42. 
El Shaer HM (2004). Potentiality of halophytes as animal fodder under arid conditions of Egypt. Rangeland and Pasture Rehabilitation in Mediterranean Areas. In: Cahier Options Méditerranéennes, 62: 369-374. Available at: http://om.ciheam.org/article.php?IDPDF=4600190

El-Katch MI, Soltan MA and Essi MS (2016). Effect of Pediococcus spp. Supplementation on growth performance, nutrient digestibility and some blood serum biochemical changes of fattening lambs. Alexandria Journal of Veterinary Science, 49(1): 44-54. DOI: http://dx.doi.org/10.5455/ajvs.210911

Fahmy AA, Youssef kM and El Shaer HM (2010). Intake and nutritive value of some salt-tolerant fodder grasses for sheep under saline conditions of South Sinai, Egypt. Small Ruminant Research, (91): 110-115. DOI:https://doi.org/10.1016/j.smallrumres. 2009.11.023

Flores C, Caja G, Casals R, Albanell E and Such X (2008). Performance of dairy ewes fed diets with a fibrolytic enzyme product included in the concentrate during the suckling period. Animal, 2:962-968. DOI: 10.1017/S1751731108001961.

Gado H (1997). Effect of enzymatic treatments for poor quality roughages on fiber digestibility and nitrogen metabolism in Baladi goats. Egyptian Journal of Nutrition and Feeds, 1(Special Issue): 49-56.

Gado HM and Salem AZM (2008). Influence of exogenous enzymes from anaerobic source on growth performance, digestibility, ruminal fermentation and blood metabolites in lambs fed of orange pulp silage in total mixed ration. In: 59th Annual Meeting of the European Association for Animal Production, Vilnius, Lithuania, August 24-27, p. 228.

Gado HM, Metwally HM, El-Basiony AA, Soliman HS and Abd El-Galil ER (2007). Enzymatic treatments of sugarcane bagasse by different sources of cellulase enzymes. Egyptian Journal of Nutrition and Feeds, 10 (2): 607-620. https://www.researchgate.net/publication/320586091

Gado HM, Salem AZM, Odongo NE and Borhami BE (2011). Effect of exogenous enzymes ensiled with orange pulp on digestion and growth performance in lambs. Animal Feed Science and Technology, 165: 131-136. DOI: 10.1016/j.anifeedsci.2011.02.016.

Gado HM, Salem AZM, Robinson PH and Hassan M (2009). Influence of exogenous enzymes on nutrient digestibility, extent of ruminal fermentation as well as milk production and composition in dairy cows. Animal Feed Science and Technology, 154: 3646. DOI: org/10.1016/j.anifeedsci.2009.07.006.

Ganong WF (1999). Thyroid gland. In: review of medical physiology. 7th edition, Appleton and Lange California p.o.box954, beirot, Lebanon, pp. 290-305.

Gomaa AAAI, Mohamed MY, Saba FE, Ibrahim EMM, El Badawy AA and El-Giziry AA (2016). Growth performance of Ossimi lambs as affected by treated rice straw by enzymes ZAD effective microorganisms. Egyptian Journal of Nutrition and Feeds, 19(2): 243-254.

Grazul-Bilska AT, Caton JS, Borowczyk E, Arndt W, Bilski JJ, Weigl RM, Kirsch JD, Redmer DA, Reynolds LP and Vonnahme KA (2007). Effects of overnutrition and undernutrition on serum metabolic hormones and estradiol-17 $\beta$ concentration in sheep. Proceedings, Western Section, American Society of American Science, 58: 299-303.

Helal HG, Abo Bakr S, Eid EY and El Shaer HM (2018a). Productive performance of Barki ewes fed halophytes added with Propionibacteria freudenreichii under saline conditions, Research Journal of Animal and Veterinary Sciences, 10(2): 18-27. DOI: $10.22587 /$ rjavs.2018.10.2.3.

Helal HG, Eid EY, Nassar MS, Badawy HS and El Shaer HM (2018b). Comparative nutritional studies of ewes and does fed salt tolerant plants under desert condition. Journal of Nature and Science, 16: 62-72. DOI:10.7537/marsnsj160618.10

Ibrahim NH, El-Hawy AS, El-Bassiony MF, Younis FE and Abo Bakr S (2018). Effect of Feeding Salt Tolerant Plants Silage on Productive Performance and Biochemical Changes of Barki Ewes and their Lambs during the First Month Post-Partum. Journal of Animal and Poultry Production, Mansoura University, 9(8): 337-344.

Kearl LC (1982). Nutrient requirements of ruminants in developing countries. Int. Feedstuffs Inst., Utah, USA.

Kewan KZ, Salem FA, Salem AZM, Abdou AR, El-Sayed HM, Eisa SS, Zaki EA and Odongo NE (2019). Nutritive utilization of Moringa oleifera tree stalks treated with fungi and yeast to replace clover hay in growing lambs. Agroforestry systems, 93: 161173. DOI: http://dx.doi.org/10.1007/s10457-017-0158-6

Kholif AE, Abdoa MM, Aneleb UY, El-Sayed MM and Morsy TA (2017). Saccharomyces cerevisiae does not work synergistically with exogenous enzymes to enhance feed utilization, ruminal fermentation and lactational performance of Nubian goats. Livestock Science, 206: 17-23. DOI: https://doi.org/10.1016/j.livsci.2017.10.002

Krause M, Beauchemin KA, Rode LM, Farr BI and Norgaard P (1998). Fibrolytic enzyme treatment of barley grain and source of forage in high-grain diets fed to growing cattle. Journal of Animal Science, 67: 2912-2920. DOI: 10.2527/1998.76112912x.

McAllister TA, Hristov AN, Beauchemin KA, Rode LM and Cheng KJ (2003). Enzymes in ruminant diets. Agriculture and Agri-Food Canada (AAFC), Department of Animal Science, University of British Columbia, Lethbridge, Canada. DOI:10.3923/ajas.2015.85.99.

McAllister TA, Hristov AN, Beauchemin KA, Rode LM and Cheng KJ (2001). Enzymes in ruminant diets. In: Bedford, M., Partridge, G. (Eds.), Enzymes in Farm Animal Nutrition. CABI Publishing, Oxon, UK, pp. 273-298.

Mohamed MI and Abou-Zeina AA (2008). Effect of dietary supplementation with biologically treated suger beet pulp on performance and organs function in goat kids. American-Eurasian Journal of Agricultural and Environmental Sciences, 4(4): 410-416.

Morsy TA, Kholif AE, Kholif SM, Kholif AM, Sun E and Salem AZM (2016). Effect of two enzyme feed additives on digestion and milk production in lactating Egyptian buffaloes. Annals of Animal Science, 16 (1): 209-222. DOI: https://doi.org/10.1515/aoas2015-0039.

Mousa MT and Shetaewi MM (1994). Crossing local Ossimi sheep with imported Chios to improve milk production and pre-weaning lamb gains. Assiut Veterinary Medical Journal, 30: 76-86. 
Nassar MS, El Shereef Afaf and Abo Bakr S (2017). Influence of feeding garlic plant either as powder or oil on reproductive performance of ewes. GSC Biological and Pharmaceutical Sciences, 1(3): 59-61. DOI:https://doi.org/10.30574/gscbps.2017.1.3.0064

Qasim SA, Abeer AS, Alia AE and Hadeel ARH (2018). The Effect of Seasonal Variation on Thyroid Hormones in Iraqi Patients. International Journal of Pharmaceutical Quality Assurance, 9(4): 405-409. Available at: http://impactfactor.org/PDF/IJPQA/9/IJPQA,Vol9,Issue4,Article9.pdf

Refat B, Christensen DA, McKinnon JJ, Yang W, Beattie AD, McAllister TA, Eun JS, Abdel-Rahman GA and Yu P (2018). Effect of fibrolytic enzymes on lactational performance, feeding behavior, and digestibility in high-producing dairy cows fed a barley silage-based diet. Journal of Dairy Science,101(9): 7971-7979. https://doi.org/10.3168/jds.2017-14203

Rode LM, Yang WZ and Beauchemin KA (1999). Fibrlytic enzyme supplements for dairy cows in early lactation. Journal of Dairy Science, 82: 2121. DOI: 10.3168/jds.S0022-0302(99)75455-X.

Sabbah MA, El-Shaer HM, Youssef KM, Ali MA and Abo Bakr S (2009). Impact of feeding biologically treated wheat straw on the production performance of goats in North Sinai. World Journal of Agricultural Science, 5(5): 535-543.

Saleem AM and Zanouny AI (2016). Effect of two levels of probiotic supplementation on performance, digestibility and some blood constituents in weaned lambs. Egyptian Journal of Nutrition and Feeds, 19(2): 265-275.

Saleem AM, Zanouny AI and Singer AM (2017). Growth performance, nutrients digestibility, and blood metabolites of lambs fed diets supplemented with probiotics during pre- and post-weaning period. Asian- Australasian Journal of Animal Science, 30(4): 523-530. DOI:https://doi.org/10.5713/ajas.16.0691

Salem AZM, Alsersy H, Camacho LM, El-Adawy MM, Elghandour MM, Kholif AE, Rivero N, Alonso MU and Zaragoza A (2015). Feed intake, nutrient digestibility, nitrogen utilization and ruminal fermentation activities in sheep fed Atriplex halimus ensiled with three developed enzymes cocktails. Czech Journal of Animal Science, 60(4):185-194. DOI: 10.17221/8133-CJAS.

Salem AZM, El-Adawy MM, Salem MZM and Hassan AA (2004). Effect of probiotics fed as additives on the activity of isolated and characterized lactic acid intestinal bacteria to inhibit Escherichia coli-10 in sheep. Egyptian Journal of Nutrition and Feeds, 7: 167-184.

SAS (2004). SAS User's Guide: Statistics. Release. 9.1. Ed., SAS Inst. Inc., Cary, N.C., USA.

Shaltout KH, EL-Komi THM and Ebrahem M (2012). Seasonal variation in the phytomass, chemical composition and nutritional value of Azolla filiculoides Lam. Along the water courses in the Nile Delta, Egypt. Feddes Repertorium, 123(1): 37-49. DOI: 10.1002/fedr.201200001.

Sujani S and Seresinhe RT (2015). Exogenous enzymes in ruminant nutrition: A review. Asian Journal of Animal Science, 9(3):85-99. DOI: 10.3923/ajas.2015.85.99.

Thakur SS, Verma MP, Ali B, Shelke SK and Tomar SK (2010). Effect of exogenous fibrolytic enzyme supplementation on growth and nutrient utilization in Murrah buffalo calves. Indian Journal of Animal Science, 80: 1217-1219.

Titi HH and Lubbadeh WF (2004). Effect of feeding cellulose enzyme on productivity responses of pregnant and lactating ewes and goats. Small Ruminant Research, 52:137-143. DOI:org/10.1016/S0921-4488(03)00254-2.

Yang WZ, Beauchemin KA and Rode LM (2000). A comparison of methods of adding fibrolytic enzymes to lactating cow diets. Journal of Dairy Science, 83: 2512-2516. DOI: 10.3168/jds.S0022-0302(00)75143-5. 